\title{
A new species of Dactylolabis (Idiolabis) Alexander, 1931 from the Eocene Baltic amber and its relationships among Dactylolabinae (Diptera: Limoniidae)
}

\author{
Iwona Kania and Wiesław Krzemiński
}

\begin{abstract}
A new species - Dactylolabis (Idiolabis) ryszardi n. sp. from Eocene Baltic amber is described. It is the third species of this extinct subgenus to be described and is known exclusively from Eocene Baltic amber. The distinctive features of the newly described species are the character of wing venation, especially the shape of discal cell, characteristically indented in upper distal corner by the position of $\mathrm{dM}_{1+2}$ shifted to $1 / 3$ of $d$-cell, and the morphology of the hypopygium. A parsimony analysis of type species of extant taxa and extinct species of the genus Dactylolabis from Baltic amber is provided based on 25 morphological characters. The analysis confirms the status of extinct subgenera from the Eocene Baltic amber currently recognized within the genus Dactylolabis and shows the modern and fossil taxa grouped separately.
\end{abstract}

Iwona Kania. Department of Environmental Biology, Rzeszów University, Zelwerowicza 4, 35-601 Rzeszów, Poland. ikania@univ.rzeszow.pl

Wiesław Krzemiński. Institute of Systematic and Evolution of Animals, Polish Academy of Sciences, Sławkowska 17, 31-016 Kraków, Poland. krzeminski@muzeum.pan.krakow.pl

Keywords: fossil insects; inclusions; taxonomy; new species; evolution; parsimony analysis

\section{INTRODUCTION}

Limoniidae are medium- or small-sized, rarely large, crane flies (Diptera, Tipuloidea). The antennae are, in most species, 14- or 16-segmented (rarely 6-, 10-, or 17-segmented or more), usually verticillate (with whorls of setae) and sometimes pectinate or serrate (Rhipidia Meigen, 1818). The wings are monochromatic or patterned (in females more often than in males), sometimes shortened or reduced. In Limoniidae the subcosta always ends in the costa. Additional cross-veins are sometimes present. Discal cell is sometimes opened. The genitalia of males have a large separated gonocoxae and one or two pairs of appendages, which are sometimes greatly folded. The ovipositor has usually sclerotized cerci (Alexander and Byers, 1981; Speiser, 1909; Watson and Dallwitz, 2003). Limoniidae is a large family with over 11,000 described species in 147 genera (Oosterbroek, 2014). The representatives of this group are found in fossil res-

http://zoobank.org/16D2DF08-A8D8-482E-A9C9-F3928C14B46E

PE Article Number: 18.1.4A

Copyright: Palaeontological Association February 2015

Submission: 15 March 2014. Acceptance: 5 January 2015

Kania, Iwona and Krzemiński, Wiesław. 2015. A new species of Dactylolabis (Idiolabis) Alexander, 1931 from the Eocene Baltic amber and its relationships among Dactylolabinae (Diptera: Limoniidae). Palaeontologia Electronica 18.1.4A: 1-15.

palaeo-electronica.org/content/2015/1047-eocene-crane-fly-from-baltic-amber 
ins as rock imprints and inclusions (Evenhuis, 1994; Krzemiński and Ansorge, 1995; Krzemiński, 2000c, 2002; Krzemiński and Arillo, 2008; Hao and Ren, 2009; Lukashevich, 2009). Few remains are derived from the Cretaceous amber deposits of Lebanon, Jordan, Spain and Myanmar (Podenas, 2000; Podenas et al., 2001; Krzemiński, 2004; Krzemiński and Arillo, 2007; Perrichot et al., 2007; Podenas and Poinar, 2009; Kania et al., 2013a; Krzemiński et al., 2014), the Palaeocene amber of Sakhalin (Krzemiński and Krzemińska, 1994); Eocene Baltic amber (Krzemiński, 1998a, 1998b; Podenas, 1999a, 1999b, 1999c; Krzemiński, 2000a, 2000b, 2001; Podenas, 2002, 2003a, 2003b, 2003c, 2003d, 2004; Podeniene et al., 2004; Podenas, 2005, 2006a, 2006b; Krzemiński et al., 2010; Kania et al., 2011; Podenas and Weiterschan, 2011; Kania and Krzemiński, 2012; Kania et al., 2013b; Kopeć and Kania, 2013; Kania, 2014), Miocene Dominican and Mexican ambers (Evenhuis, 1994; Podenas and Poinar, 1999; Krzemiński and Evenhuis, 2000; Podenas and Poinar, 2001, 2012), with the oldest record as imprints dating to the Middle Triassic (Krzemiński, 1992; Shcherbakov et al., 1995; Krzemiński and Krzemińska, 2003).

The extant genera of Limoniidae are grouped into four subfamilies (Stary, 1992; Oosterbroek, 2014): Chioneinae Rondani, 1841, with 60 genera and 81 subgenera (= Eriopterinae van der Wulp, 1877; see Starý, 1992), Dactylolabinae Alexander, 1920 (1 genus, 4 subgenera), Limnophilinae Bigot, 1854 (52 genera, 57 subgenera), and Limoniinae Speiser, 1909 (34 genera, 73 subgenera).

The Dactylolabinae is a small subfamily comprising 65 species in the genus Dactylolabis Osten Sacken, 1860, divided into four subgenera. The group was revised by Alexander (1920) largely on the basis of characters of their larvae. Later features of the subfamily were discussed by Starý (1992), concluding the group was the most primitive offshot of Limoniidae. Only four extant subgenera were described among the single genus of this subfamily, Bothrophorus Savchenko and Plyushtch, 1984 (1 species), Coenolabis Savchenko, 1969 (4 species), Dactylolabis Osten Sacken, 1860 (58 species) and Eudactylolabis Alexander, 1950 (2 species).

Fossil representatives of Dactylolabinae are rare. The first five fossil species attributed to Dactylolabis were described from Baltic amber by Meunier (1906a, 1906b). According to Alexander (1931), none of these species belongs to this genus. The fossil Dactylolabinae are classified in
Dactylolabis s.str. (2 species), plus the extinct subgenera Aurolabis Podenas, 2003a (1 species), Eobothrophorus Podenas, 2003a (4 species), Eolabis Podenas, 2003a (5 species), and Idiolabis Alexander, 1931, exclusively from the Eocene Baltic amber (2 species) (Alexander, 1931; Krzemiński, 2000a). One species - Dactylolabis tenuis Statz, 1944 - was described from sedimentary rocks (Rott, Miocene of Germany; Statz, 1944) and remains unplaced in any subgenus.

Alexander (1931) in his monograph on fossil crane flies described two species representing two different subgenera, Dactylolabis (Dactylolabis) vetusta Alexander, 1931 and Dactylolabis (Idiolabis) terebrella Alexander, 1931. More fossils of this genus, including descriptions of several extinct subgenera and species from Baltic amber were added subsequently by Krzemiński (2000a), Podenas (2003a, 2005), Krzemiński et al. (2010), and Podenas and Weiterschan (2011) (Table).

\section{MATERIAL AND METHODS}

The present study was based on a specimen from the collections of the Institute of Systematic and Evolution of Animals, Polish Academy of Sciences (ISEA PAS). The specimen was studied using a Nikon SMZ 1500 stereomicroscope. The photographs to analyze were taken with a Nikon DS-Fi1 camera equipped with a microscope. The drawings were made on the basis of the specimen and photographs. The measurements of the specimen were taken with NIS-Elements D 3.0 software. The nomenclature of wing venation follows Krzemiński et al. (2010) and terminology of male genitalia follows Podenas (2003a).

Placement of this species within the Dactylolabis reported from Eocene Baltic amber was tested with the use of Maximum Parsimony (MP) criterion, implemented in TNT software package, with the 'New Technology Search' (Goloboff et al., 2008). The type species of extant Dactylolabis subgenera not yet reported as fossils were also included in the analysis. Limnophila pictipennis (Meigen, 1818) - type species of the genus Limnophila Macquart, 1834 was selected as the outgroup as Limnophilinae are closely related to Dactylolabinae (Ribeiro, 2008). The morphological data for the matrix were compiled into Nexus file using Mesquite v. 3.01 (Maddison and Maddison, 2014). All 25 characters were treated as unordered and unweighted (Table). Unambiguous characters were mapped and analyzed using WinClada 1.00.08, under fast optimization (Nixon, 2002). Tree file 
TABLE. The data matrix.

\begin{tabular}{|c|c|c|c|c|c|c|c|c|c|c|c|c|c|}
\hline & 1 & 2 & 3 & 4 & 5 & 6 & 7 & 8 & 9 & 10 & 11 & 12 & 13 \\
\hline $\begin{array}{l}\text { Limnophila pictipennis (Meigen, } \\
\text { 1818) }\end{array}$ & 1 & 1 & 0 & 0 & 0 & 0 & 0 & 0 & 1 & 0 & 1 & 0 & 1 \\
\hline $\begin{array}{l}\text { Dactylolabis (Aurolabis) labis } \\
\text { Podenas, } 2003 a\end{array}$ & 0 & 1 & 0 & 0 & 1 & 0 & 1 & 1 & 0 & 0 & 1 & 1 & 1 \\
\hline $\begin{array}{l}\text { D. (Bothrophorus) monstrosa } \\
\text { (Savchenko, 1971) }\end{array}$ & 1 & 0 & 0 & 1 & 0 & 0 & 0 & 0 & 0 & 0 & 0 & 0 & 0 \\
\hline $\begin{array}{l}\text { D. (Coenolabis) aberrans } \\
\text { Savchenko, } 1963\end{array}$ & 1 & 0 & 0 & 1 & 0 & 0 & 0 & 0 & 0 & 0 & 0 & 1 & 1 \\
\hline $\begin{array}{l}\text { D. (Dactylolabis) montana (Osten } \\
\text { Sacken, 1860) }\end{array}$ & 1 & 0 & 0 & 1 & 0 & 0 & 0 & 0 & 0 & 0 & 0 & 0 & 1 \\
\hline $\begin{array}{l}\text { D. (Dactylolabis) amberifis } \\
\text { Podenas, } 2005\end{array}$ & 1 & $?$ & $?$ & 0 & 0 & 0 & 0 & 0 & 1 & 1 & $?$ & 0 & 1 \\
\hline $\begin{array}{l}\text { D. (Dactylolabis) viduus Podenas, } \\
2005\end{array}$ & $?$ & $?$ & 0 & 0 & 0 & 1 & 0 & 0 & 0 & 1 & $?$ & 0 & 1 \\
\hline $\begin{array}{l}\text { D. (Eobothrophorus) alna } \\
\text { Podenas, } 2003 a\end{array}$ & 0 & 1 & 0 & 1 & 0 & 0 & 0 & 0 & 0 & 0 & 1 & 1 & 0 \\
\hline $\begin{array}{l}\text { D. (Eobothrophorus) altata } \\
\text { Podenas, 2003a }\end{array}$ & 0 & 1 & 0 & 1 & 0 & 0 & 0 & 0 & 0 & 0 & 1 & 1 & 0 \\
\hline $\begin{array}{l}\text { D. (Eobothrophorus) hoffeinsorum } \\
\text { Krzemiński et al., } 2010\end{array}$ & 0 & 1 & 0 & 1 & 0 & 0 & 0 & 0 & 0 & 0 & 1 & 1 & 0 \\
\hline $\begin{array}{l}\text { D. (Eobothrophorus) lauryni } \\
\text { Podenas, 2003a }\end{array}$ & 0 & 1 & 0 & 1 & 0 & 0 & 0 & 0 & 0 & 0 & 1 & 1 & 0 \\
\hline $\begin{array}{l}\text { D. (Eolabis) ambustus Podenas, } \\
2005\end{array}$ & 0 & 1 & 0 & 1 & 0 & 0 & 0 & 1 & 1 & 1 & $?$ & 1 & 0 \\
\hline $\begin{array}{l}\text { D. (Eolabis) artis Podenas \& } \\
\text { Weiterschan, } 2011\end{array}$ & 0 & 1 & 0 & 1 & 0 & 0 & 1 & 1 & $?$ & 0 & $?$ & 1 & 0 \\
\hline $\begin{array}{l}\text { D. (Eolabis) latusta Podenas, } \\
2003 a\end{array}$ & 0 & 1 & 0 & 1 & 0 & 1 & 0 & 0 & 0 & 1 & 1 & 1 & 0 \\
\hline $\begin{array}{l}\text { D. (Eolabis) vetusta Alexander, } \\
1931\end{array}$ & 0 & 1 & 0 & 1 & 0 & 0 & 0 & 0 & 1 & 1 & 1 & 1 & 0 \\
\hline $\begin{array}{l}\text { D. (Eolabis) vyshniauskasi } \\
\text { Podenas, } 2005\end{array}$ & 0 & 1 & 0 & 1 & 0 & 0 & 0 & 0 & 1 & 1 & 1 & 1 & 0 \\
\hline $\begin{array}{l}\text { D. (Eudactylolabis) damula } \\
\text { (Osten Sacken, 1877) }\end{array}$ & 1 & 0 & 0 & 1 & 0 & 0 & 0 & 0 & 0 & 0 & 0 & 0 & 0 \\
\hline $\begin{array}{l}\text { D. (Idiolabis) christelae } \\
\text { Krzemiński, 2000a }\end{array}$ & 0 & 1 & 1 & 0 & 0 & 0 & 0 & 0 & 0 & 0 & 1 & 1 & 0 \\
\hline D. (Idiolabis) ryszardi sp. nov. & 0 & 1 & 0 & 0 & 0 & 0 & 0 & 0 & 0 & 0 & 1 & 1 & 0 \\
\hline $\begin{array}{l}\text { D. (Idiolabis) terebrella Alexander, } \\
1931\end{array}$ & 0 & 1 & 0 & 0 & 0 & 0 & 0 & 0 & 0 & 0 & 1 & 1 & 0 \\
\hline
\end{tabular}

received were adjusted using Corel Draw X3 and Photo-Paint software.

The 25 morphological characters observed in the fossil material and used for analysis are listed in the Appendix. The data matrix given is partly based on morphological features according to Meigen (1818), Osten Sacken (1860, 1877), Alexander (1931), Savchenko (1963, 1971), Krzemiński (2000a), Podenas (2003a, 2005), Krzemiński et al. (2010), and Podenas and Weiterschan (2011).

\section{RESULTS}

Systematic Palaeontology

Order DIPTERA Linnaeus, 1758

Family LIMONIIDAE Speiser, 1909 
TABLE (part 2)..

\begin{tabular}{|c|c|c|c|c|c|c|c|c|c|c|c|c|}
\hline & 14 & 15 & 16 & 17 & 18 & 19 & 20 & 21 & 22 & 23 & 24 & 25 \\
\hline $\begin{array}{l}\text { Limnophila pictipennis (Meigen, } \\
\text { 1818) }\end{array}$ & 0 & 0 & 0 & 0 & 0 & 0 & 0 & 0 & 0 & 0 & 0 & 0 \\
\hline $\begin{array}{l}\text { Dactylolabis (Aurolabis) labis } \\
\text { Podenas, 2003a }\end{array}$ & 0 & 0 & 1 & 0 & 0 & 0 & 0 & 0 & 0 & 0 & 0 & 0 \\
\hline $\begin{array}{l}\text { D. (Bothrophorus) monstrosa } \\
\text { (Savchenko, 1971) }\end{array}$ & 0 & 0 & 1 & 0 & 0 & 1 & 0 & 0 & 0 & 0 & 0 & 0 \\
\hline $\begin{array}{l}\text { D. (Coenolabis) aberrans } \\
\text { Savchenko, } 1963\end{array}$ & 0 & 0 & 0 & 1 & 0 & 0 & 0 & 0 & 0 & 0 & 0 & 0 \\
\hline $\begin{array}{l}\text { D. (Dactylolabis) montana (Osten } \\
\text { Sacken, 1860) }\end{array}$ & 0 & 0 & 0 & 0 & 0 & 0 & 0 & 0 & 0 & 0 & 0 & 0 \\
\hline $\begin{array}{l}\text { D. (Dactylolabis) amberifis } \\
\text { Podenas, } 2005\end{array}$ & 0 & 0 & 0 & 0 & 0 & 1 & 0 & 0 & 0 & 0 & 0 & 1 \\
\hline $\begin{array}{l}\text { D. (Dactylolabis) viduus Podenas, } \\
2005\end{array}$ & 0 & 0 & 0 & 0 & 0 & 0 & 0 & 0 & 0 & 1 & 0 & 0 \\
\hline $\begin{array}{l}\text { D. (Eobothrophorus) alna } \\
\text { Podenas, 2003a }\end{array}$ & 0 & 1 & 1 & 0 & 0 & 1 & 0 & 0 & 1 & 0 & 0 & 0 \\
\hline $\begin{array}{l}\text { D. (Eobothrophorus) altata } \\
\text { Podenas, 2003a }\end{array}$ & 0 & 1 & 1 & 0 & 0 & 1 & 0 & 0 & 0 & 1 & 0 & 0 \\
\hline $\begin{array}{l}\text { D. (Eobothrophorus) hoffeinsorum } \\
\text { Krzemiński et al., } 2010\end{array}$ & 0 & 1 & 1 & 0 & 0 & 1 & 0 & 1 & 0 & 0 & 0 & 0 \\
\hline $\begin{array}{l}\text { D. (Eobothrophorus) lauryni } \\
\text { Podenas, 2003a }\end{array}$ & 0 & 1 & 1 & 0 & 0 & 1 & 1 & 0 & 0 & 0 & 0 & 0 \\
\hline $\begin{array}{l}\text { D. (Eolabis) ambustus Podenas, } \\
2005\end{array}$ & 0 & 0 & 1 & 0 & 0 & 0 & 0 & 0 & 0 & 0 & 0 & 1 \\
\hline $\begin{array}{l}\text { D. (Eolabis) artis Podenas \& } \\
\text { Weiterschan, } 2011\end{array}$ & 0 & 0 & 1 & 0 & 0 & 0 & 0 & 0 & 0 & 0 & 0 & 1 \\
\hline $\begin{array}{l}\text { D. (Eolabis) latusta Podenas, } \\
2003 a\end{array}$ & 0 & 0 & 1 & 0 & 0 & 0 & 0 & 0 & 0 & 0 & 1 & 1 \\
\hline $\begin{array}{l}\text { D. (Eolabis) vetusta Alexander, } \\
1931\end{array}$ & 0 & 0 & 1 & 0 & 0 & 0 & 0 & 0 & 0 & 0 & 0 & 1 \\
\hline $\begin{array}{l}\text { D. (Eolabis) vyshniauskasi } \\
\text { Podenas, } 2005\end{array}$ & 0 & 0 & 1 & 0 & 0 & 0 & 0 & 0 & 0 & 0 & 0 & 1 \\
\hline $\begin{array}{l}\text { D. (Eudactylolabis) damula } \\
\text { (Osten Sacken, 1877) }\end{array}$ & 0 & 0 & 0 & 0 & 0 & 0 & 0 & 0 & 0 & 0 & 0 & 0 \\
\hline $\begin{array}{l}\text { D. (Idiolabis) christelae } \\
\text { Krzemiński, 2000a }\end{array}$ & 1 & 0 & 0 & 0 & 1 & 0 & 0 & 0 & 0 & 0 & 0 & 0 \\
\hline D. (Idiolabis) ryszardi sp. nov. & 1 & 0 & 0 & 0 & 1 & 0 & 0 & 0 & 0 & 0 & 0 & 0 \\
\hline $\begin{array}{l}\text { D. (Idiolabis) terebrella Alexander, } \\
1931\end{array}$ & 1 & 0 & 0 & 0 & 0 & 0 & 0 & 0 & 0 & 0 & 0 & 0 \\
\hline
\end{tabular}

Subfamily DACTYLOLABINAE Alexander, 1920 Genus DACTYLOLABIS Osten Sacken, 1860

Type species. Dactylolabis montana (Osten Sacken, 1860)

Subgenus IDIOLABIS Alexander, 1931

Type species. Dactylolabis (Idiolabis) terebrella Alexander, 1931
Species Dactylolabis (Idiolabis) ryszardi n. sp.

Figures 1, 2, 3

zoobank.org/107A6239-9A4A-49AE-A24E-0108DC43FBDE

Type material. Holotype: No. MP/3321 (male) Institute of Systematic and Evolution of Animals, Polish Academy of Sciences (ISEA PAS). 


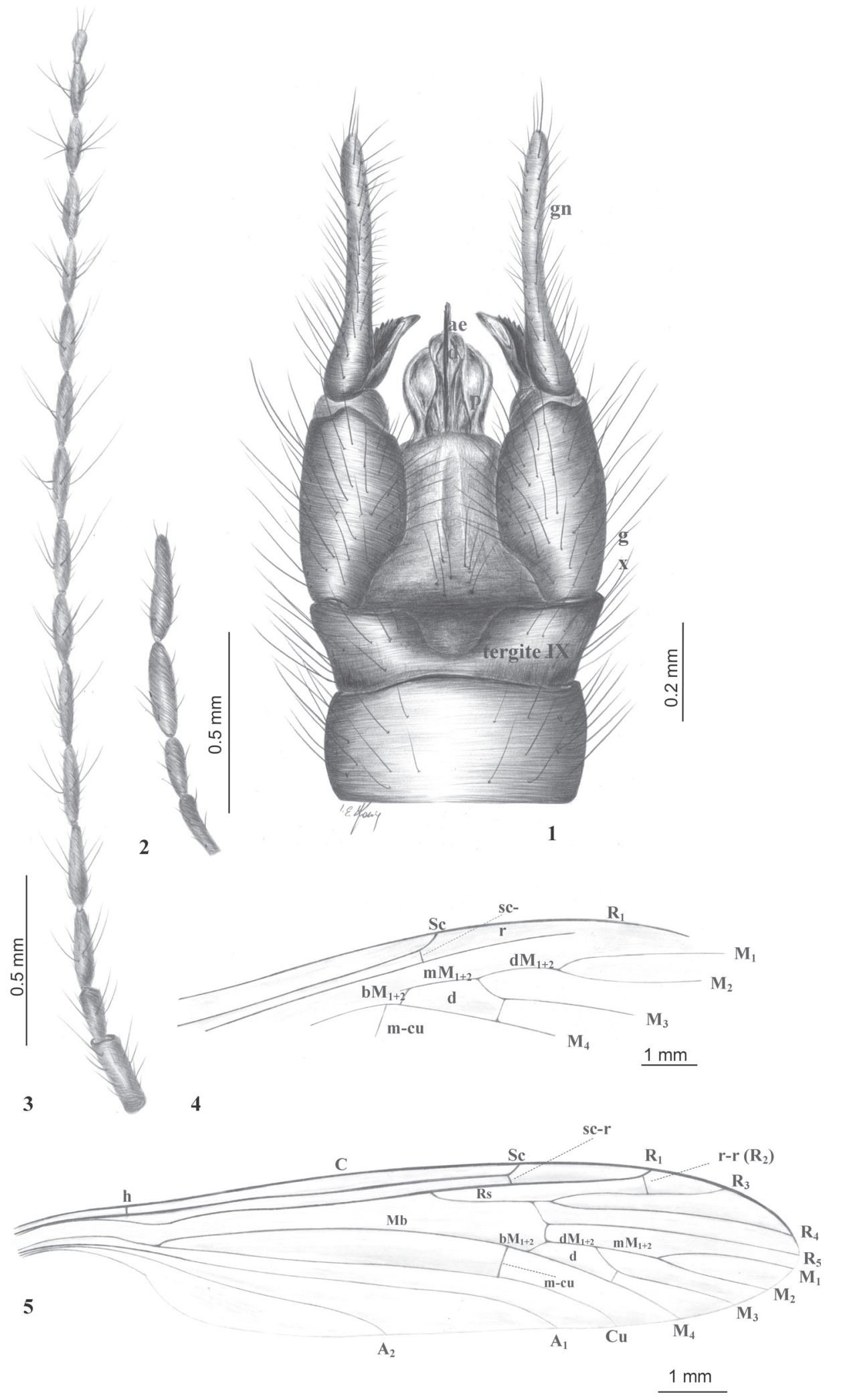

FIGURE 1. Dactylolabis (Idiolabis) ryszardi sp. nov., No. MP/3321 (male), holotype (ISEA PAS). 1, hypopygium (dorsal view); 2, palpus; 3, antenna; 4-5, wing venation; 4, well visible part of wing; 5, recontruction. Abbreviation of male hypopygium: gx-gonocoxite, gn - gonostylus, aed - aedeagus, $\mathrm{p}$ - paramere. 

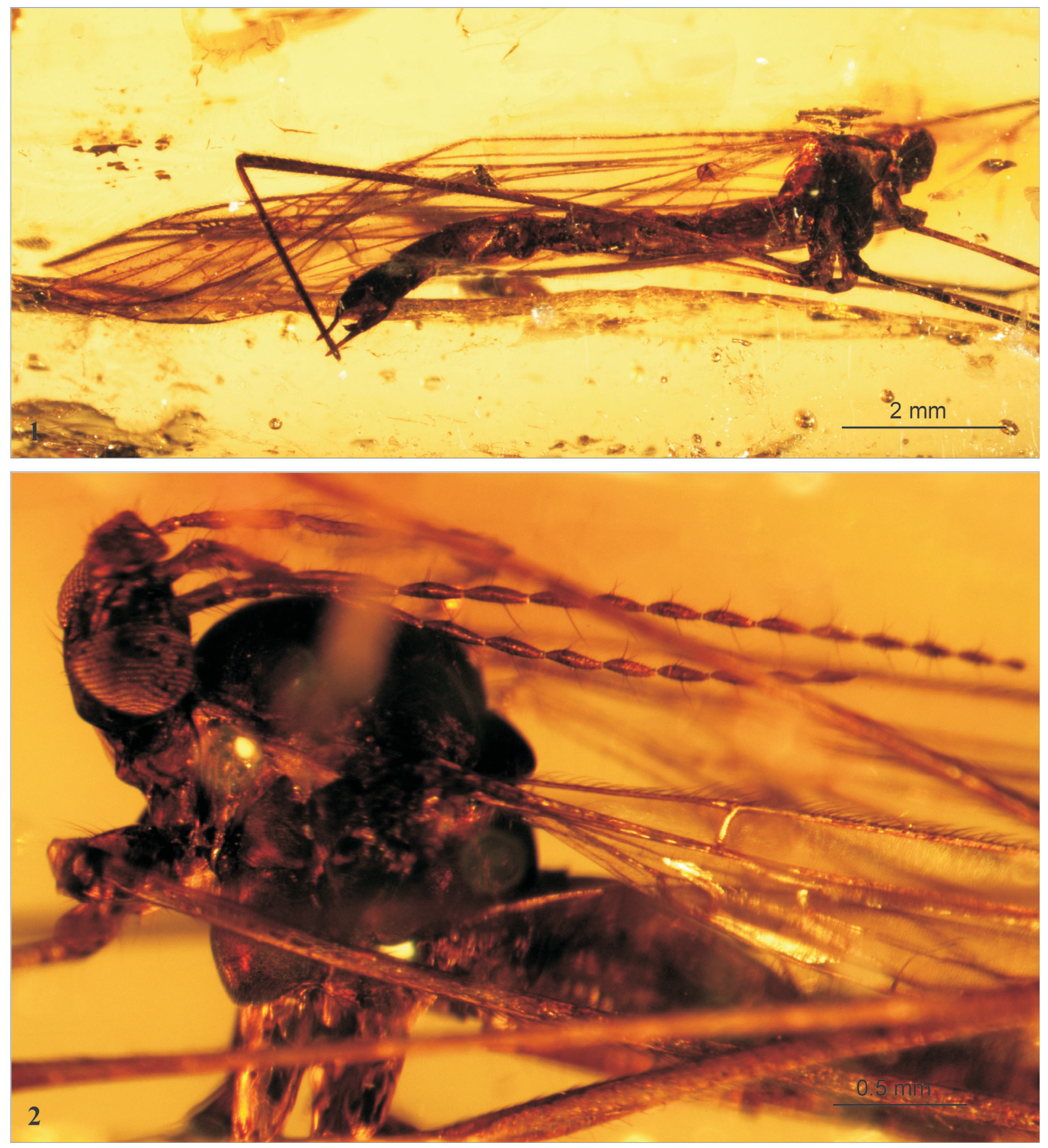

FIGURE 2. Dactylolabis (Idiolabis) ryszardi sp. nov., No. MP/3321 (male), holotype (ISEA PAS). 1, the body, lateroventral view; 2, head and thorax with appendages.

Derivatio nominis. The specific name is dedicated to Prof. Ryszard Szadziewski, eminent specialist on fossil and recent Diptera.

Diagnosis. Vein Sc ending before the fork of Rs into $\mathrm{R}_{2+3+4}$ and $\mathrm{R}_{5}$; discal cell comparatively small, characteristically indented in upper distal corner by the position of $\mathrm{dM}_{1+2}$ shifted to $1 / 3$ of $d$ cell. Cross- vein $\mathrm{m}$-cu before fork of $\mathrm{Mb}$ into $\mathrm{M}_{1+2}$ and $\mathrm{M}_{3+4}$. Tergite IX without process, indented in the middle. Gonocoxite elongated, narrow basally; gonostyle very elongated, very tiny with short, wide, distinctly crenate process at base.

Description. The male specimen is almost entirely preserved, with wings not well preserved, very dis- 

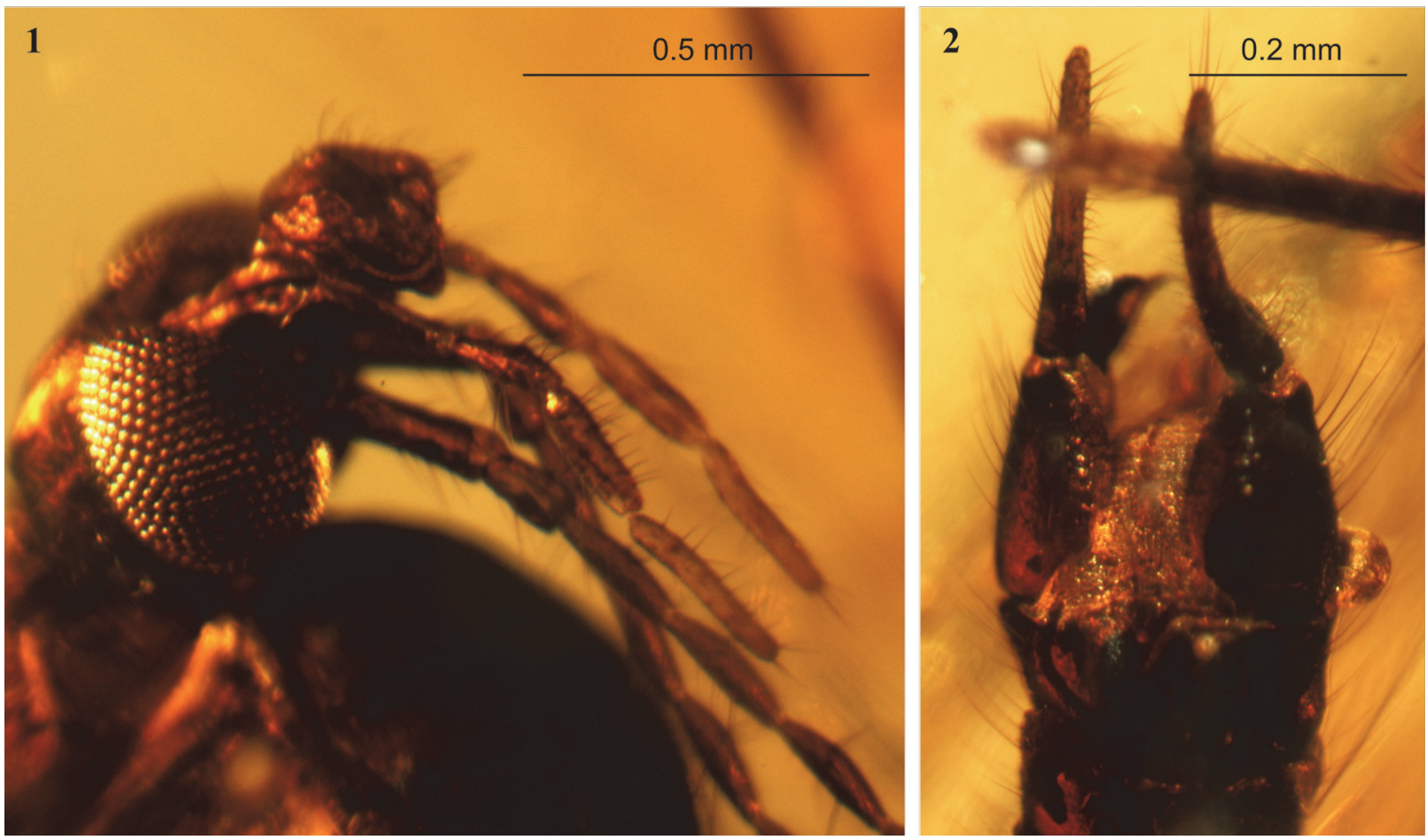

FIGURE 3. Dactylolabis (Idiolabis) ryszardi sp. nov., No. MP/3321 (male), holotype (ISEA PAS). 1, head with palpi and basal segments of antennae; 2 , hypopygium, dorsal view.

torted (Figure 2.1). Body brown, $7.30 \mathrm{~mm}$ long; wing length $9.76 \mathrm{~mm}$; antenna $3.02 \mathrm{~mm}$ long.

Head: antenna (Figures 1.3, 2.2) 16-segmented, if bent backwards, it would reach the base of abdomen; scape long, cylindrical; pedicel not very elongated, rather cylindrical; flagellomeres elongated with several, usually four, setae (verticils) on each flagellomere equal or longer than the segments bearing them; apical flagellomere approximately half as long as penultimate one and widened in distal part with four elongated setae at apex; palpus (Figures 1.2, 3.1) $0.88 \mathrm{~mm}$ long, with the last segment as long as the penultimate one.

Wing (Figure 1.4, 1.5): slightly brown infuscate, vein $\mathrm{Sc}$ ending before the fork of $\mathrm{Rs}$ into $\mathrm{R}_{2+3+4}$ and $R_{5}$; cross-vein sc-r at twice its length before the end of Sc; $R_{1}$ very long; Rs comparatively long; discal cell comparatively small, characteristically indented in upper distal corner by the position of $\mathrm{dM}_{1+2}$ shifted to $1 / 3$ of $\mathrm{d}$ cell; crossvein $\mathrm{m}$-cu before fork of $\mathrm{Mb}$ into $\mathrm{M}_{1+2}$ and $\mathrm{M}_{3+4}$; $M_{1}$ long, about two times $\mathrm{dM}_{1+2} ; \mathrm{M}_{3}$ slightly longer than discal cell.

Hypopygium (Figures 1.1, 3.2): $1.10 \mathrm{~mm}$ long, tergite IX without process, indented in the middle. Gonocoxite elongated, narrowed basally.
Gonostylus very thin, strongly elongated, with short basal process, wide, distinct denticles at margin. Aedeagus protruding; parameres shorter than aedeagus.

\section{Phylogenetic Analysis}

The parsimony analysis yielded four trees 41 steps long, with consistency index 0.60 , and retention index 0.75. The strict consensus tree (Figure 4) and majority rule (Figure 5) present similar topologies, with a difference in resolution of extinct species Dactylolabis amberifiis + Dactylolabis viduus not resolved in strict consensus (Nelsen) tree, but resolved in Majority Rule tree. The strict consensus tree revealed two main clades - clade B: [Bothrophorus monstrosa + Coenolabis aberrans + Dactylolabis montana + Eudactylolabis damula] comprising representatives of extant subgenera and second clade - clade C, comprising species of extinct subgenera with exception of above mentioned two fossils from Baltic amber, placed originally in nominative subgenus Dactylolabis, but with relationships unresolved by the present analysis. Majority rule (cut off at 50) tree presents three clades, clade A: [Dactylolabis amberifiis + Dactylolabis viduus] supported by homoplasy, very light stigma, present also in clade comprising species of 


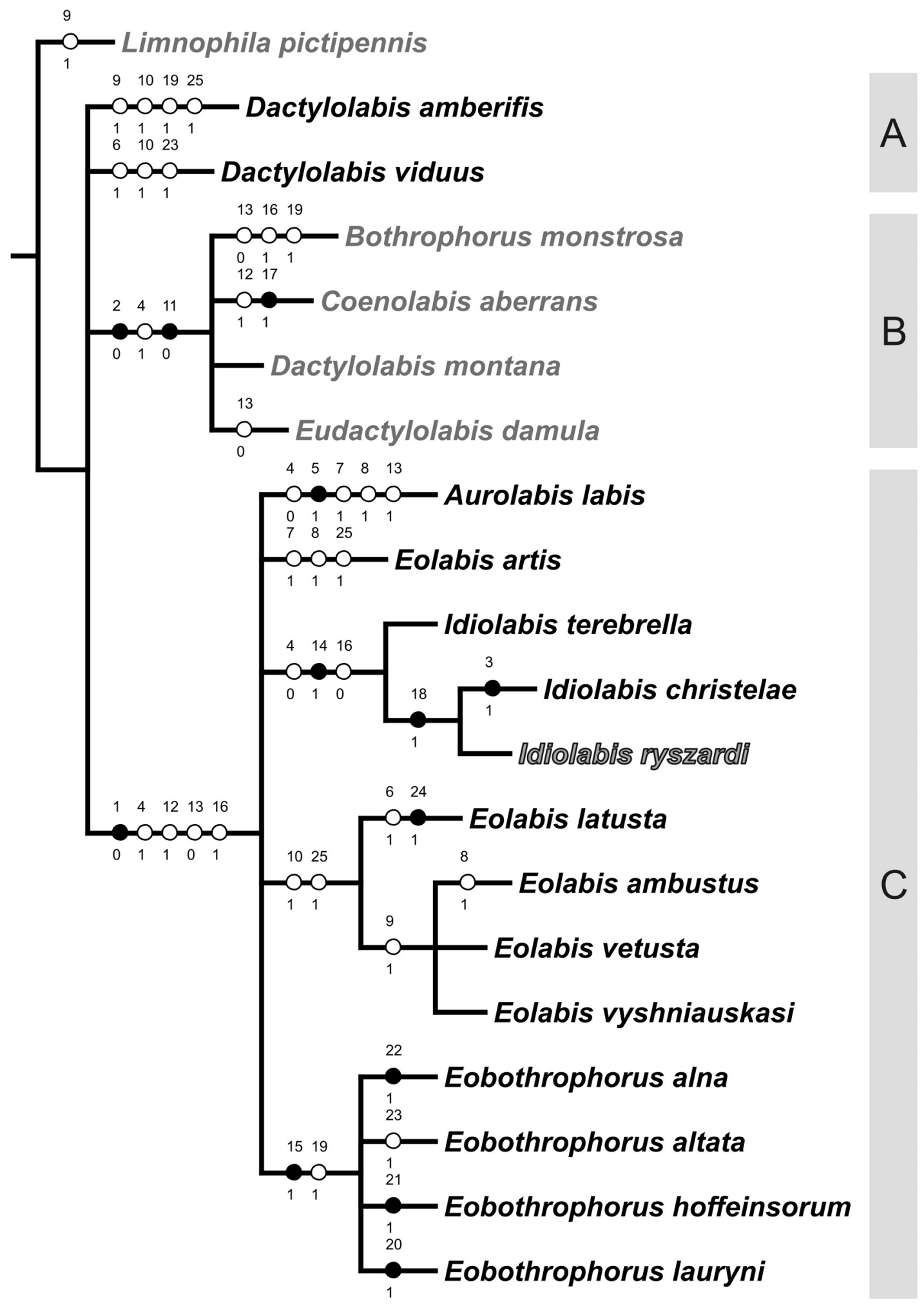

FIGURE 4. Preferred relationships tree of subgenera of the genus Dactylolabis. Filled circles indicate synapomorphies or autapomorphies; open circles indicate plesiomorphies. Extant taxa marked in grey, extinct taxa marked in black, new species noted in dark grey. Number of character above the circles, state of character below the circles. Range of clades marked in gray boxes on the right. Bootstrap values are given at the nodes. 


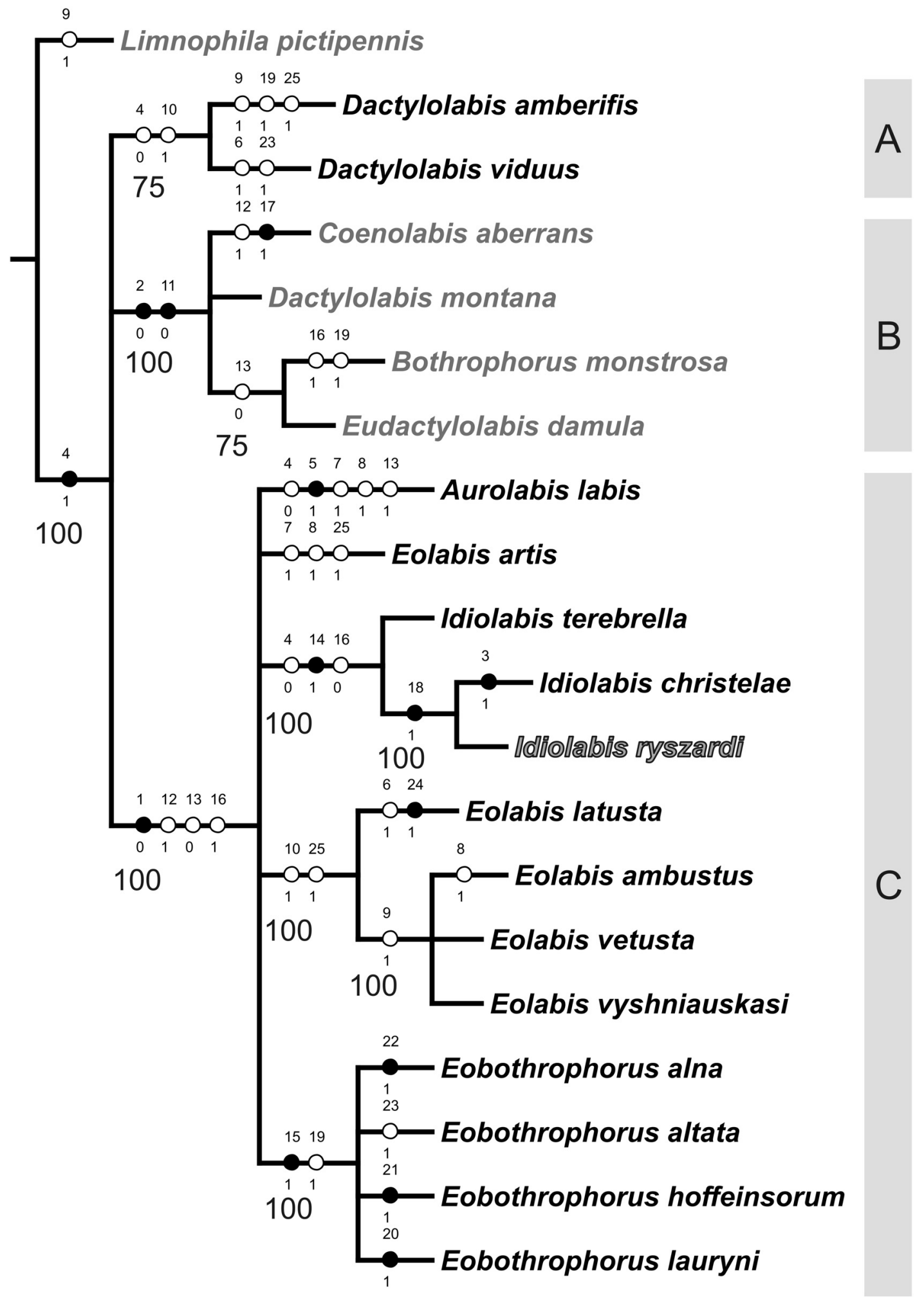

FIGURE 5. Strict consensus tree of subgenera of the genus Dactylolabis. Filled circles indicate synapomorphies or autapomorphies; open circles indicate homoplasies or plesiomorphies. Extant taxa marked in grey, extinct taxa marked in black, new species noted in dark grey. Number of characterabove the circles, state of character below the circles. Range of clades marked in gray boxes on the right. Bootstrap values are given at the nodes. 
the genus Eolabis. Separation of this group from modern Dactylolabis montana could be due to missing data for the fossils. Clade B is partly solved: [Coenolabis aberrans + Dactylolabis montana + [Bothrophorus monstrosa + Eudactylolabis damula]] and supported by two synapomorphies compound eyes occupying more than half of lateral surface of head and presence of two tibial spurs. In the strict consensus tree clade $B$ is supported by in addition by homoplastic feature - enlarged thorax. Clade [Bothrophorus monstrosa + Eudactylolabis damula] in the majority rule tree is supported by homoplasy, not produced gonocoxite, shared with majority of known fossils from Baltic amber.

Clade C presents the same topology in both trees, with species grouped in genera as recently recognized. Aurolabis labis and Eolabis artis share two homoplasies, i.e., reduction of crossvein m-m and absence of separate vein $\mathrm{M}_{2}$, the latter present also in Eolabis ambustus. Clade grouping species of the genus Idiolabis, i.e., [Idiolabis terebrella + [Idiolabis christelae+ Idiolabis ryszardi]] is present insingle synapomorphy, strong elongation of male genitalia, and two symplesiomorphies, thorax not enlarged and tergite IX and gonostylus without additional complications in structure. A single synapomorphy, gonostylus with basal lobe short, hardly reaching $1 / 3$ of the gonostylus length supports [Idiolabis christelae+ Idiolabis ryszardi]. The clade grouping majority of Eolabis species, i.e., [Eolabis latusta + [Eolabis ambustus + Eolabis vetusta + Eolabis vyshniauskasi]] is not supported by synapomorphy, but with two homoplasies. [Eolabis ambustus + Eolabis vetusta + Eolabis vyshniauskasi] is supported by homoplastic feature, tip of $A_{2}$ at the level of Rs base, shared with Limnophila pictipennis and Dactylolabis amberifis. The last clade, comprising species of the genus Eobothrophorus is supported by single synapomorphy, enlarged and compressed male genitalia, and homoplasy, IXth tergum with median lobe. Relationships within this clade remain unsolved.

\section{DISCUSSION}

The results of the analysis presented above confirmed the status of extinct subgenera from the Eocene Baltic amber currently recognized within the genus Dactylolabis. Interestingly, the modern and fossil taxa are grouped separately. The female characters of the Dactylolabis subgenera and species are too weakly known and not available for inclusion in our analysis. However, the subgenus Idiolabis is characteristic of ovipositor elongate, with tergal valves up curved, and base of IXth abdominal segment subtended by a pair of fleshy lobes, which could be interpreted as autapomorphies of this taxon. Among the subgenera of Dactylolabis the structure of ovipositor seems to be differentiated, cercus could be elongated, exceeding length of valve (subgenus Dactylolabis), cercus wide, and very short valve, tip of which just slightly reaches beyond the base of cercus (Coenolabis) or ovipositor could be relatively long and stout, the tips of the tergal valves subobtuse (Eolabis). It is unfortunate that the female characters and their disparity are too weakly recognized to be included in the present analysis.

The genus Dactylolabis Osten Sacken, 1860 comprises diversified taxa, grouped in eight subgenera, of which four are completely extinct. Only two species of recent subgenus Dactylolabis are known from Baltic amber inclusions, however, in the present analysis these species are segregated from modern species. The modern representatives of the genus Dactylolabis present high variability of morphological features, hence re-analysis of the available data for all species might well lead to the conclusion that fossils now incorporated in extinct subgenera actually could be related to extant members of Dactylolabis. To solve this problem, further studies on placement of the genus Dactylolabis and relationships of the species placed within should also include characters of juveniles (Krivosheina, 2012).

The high incidence of homoplasies revealed in our analysis could suggest that this relict group is in a recent fauna. Almost all fossils of the genus so far reported are from Eocene Baltic amber, and these species are ascribed to extinct subgenera (Evenhuis, 2014). On the one hand, it could suggest rapid diversification and high evolutionary turnover of the representatives of the Dactylolabinae during the Palaeogene; on the other hand, the data available still could be insufficient and biased for conclusive statements, e.g., due to taphonomic reasons and/or properties of taphocoenosis of Baltic amber (Szwedo and Sontag, 2009, 2013). Amber forests of the Eocene covered vast areas of Fennoscandia, and it is evident that various habitats and types of amber forests were present during the Eocene, with diverse floristic compositions that would have offered various and variable conditions (Szwedo and Sontag, 2013). In the early Eocene, low temperature seasonality was not restricted to the tropics, but extended into the high latitudes (Archibald et al., 2013). The Fennoscandia area was diverse not only in latitudinal gradient from north to south, but also in its orography, 
with elevated, montane areas and lowland areas (Cloethingh et al., 2005). This may have resulted in a high diversity of fauna, as it is observed in Eocene deposits of Okanagan Highlands (Archibald et al., 2013). It must be noted, however, that the Baltic amber samples available for study consist of a mixture of various allochthonous resins, transported to deposit from various sites in vast ancient river basins, differing in relief, climate, and biota (Zherikhin and Eskov, 2007).

The representatives of the recent Dactylobiinae taxa seem to retain some features shared with the other Limoniidae, Limnophilinae, and the extinct taxa seem to be quite specialized and apomorphic. Such specialization, including the occupation of specific ecological niches, could account for their subsequent extinction following changing environmental circumstances. The wide, Holarctic, recent distribution of the subgenus Dactylolabis could be a measure of its evolutionary success the oldest fossils of the subgenus are known from the Eocene Baltic amber - and its evolutionary capability. The other subgenera are much less numerous in species and present much narrower distributional patterns: Bothrophorus in Eastern Palaearctic (Tadjikistan), Coenolabis in Western Palaearctic (the Carpathian Mts. - Slovakia, Romania and the Caucasus Mts. - Ukraine, Russia, Georgia, Turkey), and Eudactylolabis in the Nearctic (California, Arizona). Such distributions are also interesting from a historical biogeographic perspective. However, more data, including more studies of fossils, are necessary for a fuller explanation of the evolutionary, phylogenetic, and biogeographic history of Dactylolabinae and Limoniidae.

Starý (1992) stated that Dactylolabinae are thought to represent the most primitive group of the Limoniidae. However, he noted that it is difficult to point out apomorphies for this unit, and that it is characterized by plesiomorphies. The status of Dactylobinae as a separate subfamily is under discussion (Starý, 1992; Ribeiro, 2008; Petersen et al., 2010). The position of Dactylolabis is equivocal, with no clear evidence for its placement as a monotypic subfamily or as part of also not well defined 'Limnophilinae'. The most recent studies of Petersen et al. (2010) recovered Dactylolabis as an independent lineage of uncertain affinity. More attention and further efforts to recognize morphological characteristics and morphological diversity of males and females of Dactylolabinae are necessary to resolve the relationships within this group and its relationships with the other Limoniidae.

\section{ACKNOWLEDGEMENTS}

We greatly appreciate Prof. S. Podenas (Department of Zoology of Vilnius University and Nature Research Centre, Vilnius, Lithuania) and anonymous reviewers for valuable comments and remarks.

We would like to thank Dr. J. Szwedo (Museum and Institute of Zoology, Polish Academy of Sciences, Warsaw) for the help with phylogenetic software.

\section{REFERENCES}

Alexander, C.P. 1920. The crane-flies of New York. Part II. Biology and phylogeny. Memoirs, Cornell University Agricultural Experiment Station, 38:691-1133.

Alexander, C.P. 1931. Crane-flies of the Baltic amber (Diptera). Bernsteinforschungen, 2:1-135.

Alexander, C.P. 1950. New or insufficiently-known craneflies from the Nearctic region (Diptera, Tipulidae). Part XII. Bulletin of the Brooklyn Entomological Society, 45:41-47.

Alexander, C.P. and Byers, G.W. 1981. Tipulidae. In McAlpine J.F. et al. (eds.), Manual of Nearctic Diptera. Vol. 1. Biosystematic Research Centre, Agriculture Canada, Ottawa, Ontario, Monograph, 27:153190.

Archibald, S.B., Greenwood, D.R., and Mathewes, R.W. 2013. Seasonality, montane beta diversity, and Eocene insects: testing Janzen's dispersal hypothesis in an equable world. Palaeogeography, Palaeoclimatology, Palaeoecology, 371:1-8.

Bigot, J.M.F. 1854. Essai d'une classification générale et synoptique de l'ordre des insectes diptères (3è memoire). Tribu de Tipulidii (mihi). Annales de la Sociéte Entomologique de France, (3)2:447-482.

Cloetingh, S., Ziegler, P.A., Beekman, F., Andriessen, P.A.M., Matenco, L., Bada, G., Garcia-Castellanos, D., Hardebol, N., Dèzes, P., and Sokoutis, D. 2005. Lithospheric memory, state of stress and rheology: neotectonic controls on Europe's intraplate continental topography. Quaternary Science Reviews, 24:241-304.

Evenhuis, N.L. 1994. Catalogue of the fossil flies of the world (Insecta: Diptera). Backhuys, Leiden, 1-600.

Evenhuis, N.L. 2014. Catalogue of the fossil flies of the world (Insecta: Diptera). Last revised 18 November 2014. http://hbs.bishopmuseum.org/fossilcat/

Goloboff, P.A., Farris, J.S., and Nixon, K.C. 2008. TNT, a Free Program for Phylogenetic Analysis. Cladistics, 24:774-786.

Hao, J. and Ren, D. 2009. Two new fossil species of Limoniidae (Diptera: Nematocera) from the Middle Jurassic of Northeastern, China. Entomological News, 120(2):171-178. 
Kania, I., 2014. Subfamily Limoniinae Speiser, 1909 (Diptera, Limoniidae) from Baltic amber (Eocene). The genus Dicranomyia Stephens, 1829. Zoological Journal of the Linnean Society, 170:748-778.

Kania, I. and Krzemiński, W. 2012. A new species of Palaeopoecilostola Meunier, 1899 (Diptera: Limoniidae) from the Eocene Baltic amber. Zootaxa, 3495:42-56.

Kania, I., Krzemiński, W., and Azar, D. 2013a. The oldest representative of Helius Lepeletier \& Serville 1828 (Diptera: Limoniidae) from Lebanese amber (Early Cretaceous). Insect Systematics \& Evolution, 44:231-238.

Kania, I., Krzemiński, W., and Gil, A. 2011. Revision of the genus Palaeopoecilostola Meunier, 1899 (Diptera: Limoniidae) from Baltic amber (Upper Eocene). Polish Journal of Entomology, 80(4):747-764.

Kania, I., Penar, A., and Krzemiński, W. 2013b. A new species of Dicranomyia Stephens, 1829 from Baltic amber (Diptera: Limoniidae). Annales Zoologici, 63(1):143-148.

Kopeć, K. and Kania, I. 2013. A new species of Cheilotrichia Rossi, 1848 (Diptera: Limoniidae) from Bitterfeld amber. Annales Zoologici, 63(4):537-540.

Krivosheina, N.P. 2012. Analysis of the Taxonomic Structure of the Crane Fly Family Limoniidae (Diptera) Based on the Larval Characters. Entomologicheskoe Obozrenie, 91(1):164-179.

Krzemiński, W. 1992. Triassic and Lower Jurassic stage of Diptera evolution. Mitteilungen der schweizerischen entomologischen Gesellschaft, 65:39-59.

Krzemiński, W. 1998a. Limonia (s. str.) skalskii, a new species of Limoniidae (Diptera) from the Baltic amber (Eocene). Polish Journal of Entomology, 67:299301.

Krzemiński, W. 1998b. Hexatoma (Eriocera) serafini, sp. nov., from Baltic amber (Diptera, Limoniidae). Polish Journal of Entomology, 67:309-310.

Krzemiński, W. 2000a. Fossil Tipulomorpha from Baltic amber (Upper Eocene): a new species of Dactylolabis (Idiolabis) (Diptera: Limoniidae). Polish Journal of Entomology, 69:247-250.

Krzemiński, W. 2000b. A new species and other representatives of the genus Dicranomyia (Diptera: Limoniidae) in the collection of the Museum of Amber Inclusions, University of Gdańsk. Polish Journal of Entomology, 69:347-353.

Krzemiński, W. 2000c. New information on Limoniidae (Diptera: Tipulmorpha) from the Lower Cretaceous Santana Formation (northeastern Brazil). Polish Journal of Entomology, 69:451-457.

Krzemiński, W. 2001. First record of the genus Lipsothrix Loew (Diptera: Limoniidae) in Baltic amber (Upper Eocene). Polish Journal of Entomology, 70:329-331.

Krzemiński, W. 2002. Three new species of the genus Helius Lepeletier et Serville (Diptera, Limoniidae) from the Middle Miocene of Stavropol (northern Caucasus, Russia). Acta zoologica cracoviensia, 45(4):317-320.
Krzemiński, W. 2004. Fossil Limoniidae (Diptera, Tipulomorpha) from Lower Cretaceous Burmese amber of Myanmar. Journal of Systematic Palaeontology, 2(2):123-125.

Krzemiński, W. and Ansorge, J. 1995. New Upper Jurassic Diptera (Limoniidae, Eoptychopteridae) from the Solnhofen Lithographic Limestone (Bavaria, Germany). Stuttgarter Beitrage zur Naturkunde, Ser. B. (221), $7 \mathrm{pp}$.

Krzemiński, W. and Arillo, A. 2007. Alavia neli n. gen. and $\mathrm{n}$. sp. - the first Limoniidae (Diptera) from the Lower Cretaceous amber of Alava (Spain). Alavesia, 1:11-13.

Krzemiński, W. and Arillo, A. 2008. a new species, Symplecta (Psiloconopa) penalveri n. sp. (Diptera, Limoniidae) from the Miocene of Spain. Alavesia, 2:211213.

Krzemiński, W. and Evenhuis, N. 2000. Review of Diptera paleontological records. In Papp, L. and Darvas, B. (eds.), Contributions to Manual of Palaearctic Diptera Vol. 1. Science Herald, Budapest, 535-564.

Krzemiński, W. and Krzemińska, E. 1994. A new species of Cheilotrichia (Empeda) from the Sakhalin amber (Diptera, Limoniidae). Acta zoologica cracoviensia, 37(2):91-93.

Krzemiński, W. and Krzemińska, E. 2003. Triassic Diptera: review, revisions and descriptions. Acta zoologica cracoviensia, 46 (suppl. - Fossil Insects):153184.

Krzemiński, W., Kania, I., and Azar, D. 2014. The Early Cretaceous evidence of rapid evolution of the genus Helius Lepeletier and Serville, 1828 (Limoniidae, Diptera). Cretaceous Research, 48:96-101.

Krzemiński, W., Kania, I., and Krzemińska, E. 2010. A new species of Dactylolabis (Eobothrophorus) from Baltic amber (Diptera: Limoniidae). Acta Geologica Sinica (English Edition), 84(4):768-771.

Linnaeus, C. 1758. Systema naturae per regna tria naturae, secundum classes, ordines, genera, species, cum characteribus, differentiis, synonymis, locis. Editio Decima, Vol. 1. Holmiae:1-824.

Lukashevich, E.D. 2009. Limoniidae (Diptera) in the Upper Jurassic of Shar Teg, Mongolia. Zoosymposia, 3:131-154.

Macquart, J. 1834. Histoire naturelle des Insectes. Dipteres. Roret, Paris, 1:1-578.

Maddison, W.P. and Maddison, D.R. 2014. Mesquite: a modular system for evolutionary analysis. Version 3.01. http://mesquiteproject.org

Meigen, J.W. 1818. Systematische Beschreibung der bekannten europaischen zweiflugeligen Insecten. Erster Theil. F. W. Forstmann, Aachen., xxxvi + $332+$ [1] $p$.

Meunier, F. 1906a. Monographie des Tipulidae et des Dixidae de l'ambre de la Baltique. Annales des Sciences Naturelles Zoologie, 9:349-401.

Meunier, F. 1906b. Un nouveau genre de Psychodidae et une nouvelle espèce de Dactylolabis (Tipulidae) de l'ambre de la Baltique. Naturaliste, (2)28:103-104. 
Nixon, K.C. 2002. WinClada ver. 1.00.08 Published by the author, Ithaca, NY.

Oosterbroek, P. 2014. Catalogue of the Craneflies of the World (Diptera, Tipuloidea: Pediciidae, Limoniidae, Cylindrotomidae, Tipulidae). Updated 31 Jan. 2014, Last accessed 2 February 2014. http://nlbif.eti.uva.nl/ ccw/index.php

Osten Sacken, C.R. 1860. New genera and species of North American Tipulidae with short palpi, with an attempt at a new classification of the tribe. Proceedings of the Academy of Natural Sciences of Philadelphia, 1859:197-256.

Osten Sacken, C.R. 1877. Western Diptera: Descriptions of new genera and species of Diptera from the region west of the Mississippi and especially from California. Bulletin of the United States Geological and Geographical Survey of the Territories, 3:189-354.

Perrichot, V., Nel, A., and Krzemiński, W. 2007. A new crane fly (Diptera: Limoniidae) from the Cretaceous amber of France. Alavesia, 1:75-80.

Petersen, M.J., Bertone, M.A., Wiegmann B.M., and Courtney, G.W. 2010. Phylogenetic synthesis of morphological and molecular data reveals new insights into the higher-level classification of Tipuloidea (Diptera). Systematic Entomology, 35:526-545.

Podenas, S. 1999a. Ormosia Rondani crane flies (Diptera, Limoniidae) from the Baltic amber. Acta Zoologica Lituanica, 9(1):183-200.

Podenas, S. 1999b. Paradelphomyia (Diptera, Limoniidae) from the Baltic amber. Acta Zoologica Lituanica. Biodiversity, 9/3:107-110.

Podenas, S. 1999c. New Cheilotrichia crane flies (Diptera, Limoniidae) from Baltic amber. Mitteilungen aus dem Geologisch-Paläontologischen Institut der Universität Hamburg, 83:239-248.

Podenas, S. 2000. New Thaumastoptera Mik, 1866 (Diptera, Limoniidae) from the Jordan amber (Lower Cretaceous). Mitteilungen aus dem GeologischPaläontologischen Institut der Universität Hamburg, 84:237-240.

Podenas, S. 2002. New species of Helius crane flies (Diptera: Limoniidae) from Baltic amber (Eocene). Mitteilungen aus dem Geologisch-Paläontologischen Institut der Universität Hamburg, 86:229238.

Podenas, S. 2003a. Dactylolabis crane flies (Diptera: Limoniidae) in Baltic amber (Eocene). Proceedings of the Academy of Natural Sciences of Philadelphia, 153(1):49-65.

Podenas, S. 2003b. A new subgenus for Trentepohlia crane flies (Diptera: Limoniidae) with elongated mouth parts, from Baltic amber (Eocene). Proceedings of the Academy of Natural Sciences of Philadelphia, 153(1):67-71.

Podenas, S. 2003c. First Rhipidia Meigen, 1818 (Diptera, Limoniidae) from Baltic amber (Eocene). Bulletin de la Société Neuchâteloise des Sciences Naturelles, 126(1):97-100.
Podenas, S. 2003d. First fossil Eloeophila Rondani, 1856 (Diptera, Limoniidae) from Baltic amber (Eocene). Mitteilungen aus dem Geologisch-Paläontologischen Institut der Universität Hamburg, 87:125130.

Podenas, S. 2004. Dicranoptycha crane flies (Diptera: Limoniidae) from Baltic amber (Eocene). Transactions of the American Entomological Society, 130(4):457-462.

Podenas, S. 2005. New Dactylolabis Osten Sacken, 1860 (Diptera, Limoniidae) from Baltic amber (Eocene). Mitteilungen aus dem Geologisch-Paläontologischen Institut der Universität Hamburg, 89:117128.

Podenas, S. 2006a. Rhabdomastix crane flies (Diptera: Limoniidae) in Baltic amber (Eocene). Proceedings of the Academy of Natural Sciences of Philadelphia, 155(1):41-66.

Podenas, S. 2006b. Idiocera Dale, 1842 (Diptera, Limoniidae) from Baltic amber (Eocene). Transactions of the American Entomological Society, 132(3-4):419425.

Podenas, S. and Poinar, G.O.1999. New crane flies (Diptera, Limoniidae) from Dominican amber. Proceedings of the Entomological Society of Washington, 101(3):595-610.

Podenas, S. and Poinar, G.O. 2001. New crane flies (Diptera: Tipulidae, Limoniidae) from Dominican and Mexican amber. Proceedings of the Entomological Society of Washington, 103(4):863-878.

Podenas, S. and Poinar, G.O. 2009. New crane flies (Diptera: Limoniidae) from Burmese amber. Proceedings of the Entomological Society of Washington, 111(2):470-492.

Podenas, S. and Poinar, G.O. 2012. New short-palped crane flies (Diptera: Limoniidae) from Mexican amber. Proceedings of the Entomological Society of Washington, 114:347-371.

Podenas, S., Poinar, G.O., and Milki, M. 2001. New crane flies (Diptera: Limoniidae) from Lebanese amber. Proceedings of the Entomological Society of Washington, 103(2):433-436.

Podenas, S. and Weiterschan, T. 2011. Two new species of short palped craneflies (Diptera Limoniidae) from Baltic amber. Transactions of the American Entomological Society, 138:149-155.

Podeniene, V., Podenas, S., and Gelhaus, J.K. 2004. First record of a crane fly larva (Diptera, Limoniidae: Chioneinae) from Baltic amber. Annals of the Entomological Society of America, 97(6):1126-1128.

Ribeiro, G.C. 2008. Phylogeny of the Limnophilinae (Limoniidae) and early evolution of the Tipulomorpha (Diptera). Invertebrate Systematics, 22:627-694.

Rondani, C. 1841. Progetto di una classificazione in famiglie degli insetti ditteri Europei. Memoria terza per servir alla ditterologia italiana. Donati, Parma, 128. 
Savchenko, E.N. 1963. New species of Dactylolabis O.$S$. (Diptera, Limoniidae) from the Crimea. Dopovidi Akademii Nauk Ukrayinskoyi RSR (B), 1963:129132. (In Ukrainian with Russian with English summaries)

Savchenko, E.N. 1969. The taxonomic status, geographical distribution and intraspecific structure of the Limoniid-fly Dactylolabis abberans Sav. (Diptera, Limoniidae). Vestnik Zoologii, 6:36-45. (In Russian)

Savchenko, E.N. 1971. A new species of Austrolimnophila Al. (Diptera, Limoniidae) from Tajikistan. Doklady Akademii Nauk Tadzhikskoi SSR, 4:58-60. (In Russian with Tajik summary)

Savchenko, E.N.. Plyushtch, G.I. 1984. On the fauna of Limoniidae (Diptera) of the Gissar mountains. 1. Entomologicheskoe Obozrenie, 63:166-185. (In Russian)

Shcherbakov, D.E., Lukashevich, E.D., and Blagoderov, V.A. 1995. Triassic Diptera and initial radiation of the order. Dipterological Research, 6:75-115.

Speiser, P. 1909. 4 Orthorapha. Orthorapha Nematocera. Wissenschaftliche Ergebnisse der Schwedischen Zoologische Expededition nach Kilimandjaro, Meru. 10 (Diptera), 31-65.

Starý, J. 1992. Phylogeny and classification of Tipulomorpha, with special emphasis on the family Limoniidae. Acta zoologica cracoviensia, 35:11-36.
Statz, G. 1944. Neue Dipteren (Nematocera) aus dem Oberoligocän von Rott. III. Familie Limnobiidae (Stelzmücken). IV. Familie: Tipulidae (Schnaken). V. Culicidae (Stechmücken). Paleontographica (A), 95:93-120.

Szwedo, J. and Sontag, E. 2009. The traps of the 'amber trap'. Amber-trapped insects trap scientists with enigmas. Denisia, zugleich Kataloge der oberösterreichischen Landesmuseen, 26: Neue Serie, 86:155169.

Szwedo, J. and Sontag, E. 2013. The flies (Diptera) say that amber from the Gulf of Gdańsk, Bitterfeld and Rovno is the same Baltic amber. Polish Journal of Entomology, 82(4):379-388.

van der Wulp, F.M. 1877. Diptera Neerlandica. I. Nijhoff, s Gravenhage, i-xviii: 1-497.

Watson, L. and Dallwitz, M.J. 2003 onwards. British insects: the families of Diptera. Version: 1st January 2012. http://delta-intkey.com/britin/dip/www/limoniid.htm

Zherikhin, V.V. and Eskov, K.Yu. 2007(2006). On the real proportions of the main arthropod groups in the Baltic amber fauna, based on representative sampling. Arthropoda Selecta, 15:173-179. 


\section{APPENDIX}

\section{THE CHARACTERS OF PARSIMONY ANALYSIS}

1. occiput somewhat extended

$$
0-\text { no } \quad 1-\text { yes }
$$

Comment. vertex separating compound eyes, sometimes broad

2. eyes rather huge, covering more than half of lateral surface of head.

$$
0-\text { no } 1 \text {-yes }
$$

3. last antennal segment approximately equal to penultimate one

$$
0-\text { no } 1-\text { yes }
$$

4. prothorax huge, elongated

$$
0-\text { no } 1-\text { yes }
$$

5. wing reduced, clearly too short for flight

$$
0-\text { no } 1 \text {-yes }
$$

6. wing venation characterized by short $\mathrm{m} 1$ which is shorter than its petiole

$$
0 \text { - no } 1 \text {-yes }
$$

7. reduction of cross-vein $\mathrm{m}-\mathrm{m}$

$$
0 \text { - no } 1 \text {-yes }
$$

8. no separate vein $\mathrm{M}_{2}$

$$
0 \text { - no } 1 \text {-yes }
$$

9. tip of $A_{2}$ at the level of Rs base

$$
0-\text { no } 1-\text { yes }
$$

10. very light stigma

$$
0 \text { - no } 1 \text { - yes }
$$

11. two tibial spurs at least on one pair of leg

$$
\text { - absent 1-present }
$$

12. one pair of gonostyles

$$
0-\text { no } 1-\text { yes }
$$

13. gonocoxite

$$
0 \text { - not produced } 1 \text { - produced }
$$

14. male genitalia strongly elongated (gonostylus more than three times as long as wide at base)

$$
0-\text { no } 1-\text { yes }
$$

15. extremely large compressed male genitalia

$$
0-\text { no } \quad 1-\text { yes }
$$

Comment. The male genital structures enlarged and laterally compressed are characteristic for the subgenus Eobothrophorus (Podenas, 2003).

16. very complicated of IX tergite and gonostylus

$$
0-\text { no } 1 \text {-yes }
$$

Comment. e.g. in Eobothrophorus ninth tergite with very long, slender median lobe, which has bifid apex is observed; in Bothrophorus ninth tegum is extremely complicated, it has median lobe with three pairs of huge conical lobes (Podenas, 2003).

17. characteristic interbasal lobe present

$$
0 \text { - no } 1 \text {-yes }
$$

18. gonostylus with basal lobe short, hardly $1 / 3$ the length of gonostylus itself

$$
0 \text { - no } 1 \text {-yes }
$$

19. ninth tergum with large medial lobe

$$
0 \text { - no } 1 \text {-yes }
$$

20. the medial processes of tergite IX branched apically into four branches

$$
0-\text { no } \quad 1-\text { yes }
$$

21. IX tergite with large processes intended into several small lobes

$$
0 \text { - no } 1 \text {-yes }
$$

22. medial lobe of tergum bifid at apex

$$
0-\text { no } 1 \text {-yes }
$$

23. medial lobe of ninth tergum more simple, without branches

$$
0 \text { - no } 1 \text {-yes }
$$

24. gonostylus with big flashy and hairy rostral lobe, which is just slightly shorter than gonostylus itself

$$
0-\text { no } \quad 1-\text { yes }
$$

25. coloration dark

$$
0-\text { no } \quad 1-\text { yes }
$$

